\author{
Monika Plaziak \\ https:// orcid.org/0000-0001-7455-504X \\ Uniwersytet Pedagogiczny w Krakowie \\ Instytut Geografii \\ Zakład Przedsiębiorczości i Gospodarki Przestrzennej \\ mplaziak@up.krakow.pl
}

\title{
ATRAKCYJNOŚĆ CENTRUM MIASTA I CENTRÓW DZIELNIC KRAKOWA W OPINII MIESZKAŃCÓW
}

\begin{abstract}
Abstrakt: W artykule zaprezentowano badania empiryczne dotyczące oceny atrakcyjności centrum miasta i centrów dzielnic administracyjnych Krakowa, opierając się na opiniach mieszkańców. Badania potwierdzają powszechne koncepcje hierarchicznego zaopatrywania się w dobra, czyli klasyczną teorię miejsc centralnych. Jak wykazały analizy, mieszkańcy Krakowa zdecydowanie częściej odwiedzają centra dzielnic niż jego centrum, co jest związane z mniejszą odległością centrów dzielnic od miejsc zamieszkania, jak również ze zróżnicowanym zagospodarowaniem, dostosowanym do odmiennych potrzeb ludności, realizowanych w obu rodzajach centrów. Stwierdzono zależność między częstszymi odwiedzinami centrum dzielnicy a częstszymi odwiedzinami centrum miasta, co może świadczyć o bardziej mobilnym stylu życia pewnej grupy osób. Respondenci oceniają centrum miasta jako atrakcyjniejsze niż centra dzielnicowe. Zdecydowanie najniższa ocena dotyczyła oferty kulturalnej i rozrywkowej w centrach dzielnic. Jedynie poczucie bezpieczeństwa w centrum miasta uzyskało niższą ocenę niż w centrach dzielnic.
\end{abstract}

Słowa kluczowe: centrum miasta, centrum dzielnicy, dzielnica administracyjna, Kraków.

\section{THE ATTRACTIVENESS OF THE CITY CENTRE AND THE DISTRICT CENTRES OF CRACOW IN INHABITANTS' OPINION}

Abstract: The article presents results of the empirical study on the evaluation of the attractiveness of the city centre and administrative district centres on the basis of inhabitants' opinions. Those results have confirmed broadly known concepts for hierarchical supplying goods - the classical theory of central places. As shown by the analysis, the residents of Cracow more likely used to visit centres of residential areas than the main city centre. It is due to lesser distance from the place of residence, as well as the different offer of both types of centres as regard to the population needs. Relationship between frequent visits the centres of administrative areas and the city one is typical for more mobile group of respondents. The inhabitants of Cracow evaluate the basic city centre generally more attractive than the district ones. By far the lowest score related to the category "culture and entertainment" in the administrative district centres. Only in terms of the sense of security the city centre received lower scores than the centres of districts.

Keywords: city centre, district centre, administrative district, Cracow.

\section{CENTRUM MIASTA A CENTRUM DZIELNICY MIESZKANIOWEJ JAKO PRZEDMIOT BADAŃ}

Centrum miasta definiuje się najczęściej jako ośrodek usługowy najwyższego stopnia $\mathrm{w}$ danej jednostce lub zespole jednostek osadniczych, dlatego za synonim centrum miasta można przyjąć określenie "centralny ośrodek usługowy" (Maik, 1997; Nowakowski, 1990). W centrum miasta znajdują się obiekty usługowe i administracyjne, $\mathrm{w}$ tym przede wszystkim handlowe, gastronomiczne, rzemieślnicze, kulturalne i rozrywkowe oraz dyspozycyjne.
Obiekty te koncentrują się na relatywnie niedużej powierzchni, raczej na zwartym obszarze, który wyraźnie odróżnia się od terenów o innym sposobie użytkowania (np. typowo mieszkaniowym, rekreacyjnym lub przemysłowym), a jest połżony w pobliżu głównego węzła komunikacyjnego danej jednostki osadniczej (Maliszowa, 1974). Centrum miasta charakteryzuje duża liczba użytkowników i ich znaczna mobilność uwidaczniająca się natężonym 
ruchem pieszych. Notuje się tam szczególnie wysoką aktywność gospodarczą i kulturalną ludności, najczęstsze kontakty społeczne oraz intensywną wymianę dóbr, usług i informacji (Mydel, 1991; Winiarczyk-Raźniak, 2006). Zachodzi tam proces koordynowania pozostałych zdecentralizowanych funkcji miejskich (Nowakowski, 1990).

Pojęcia „,centrum miasta” lub „centralny ośrodek usługowy" utożsamiane są często ze śródmieściem, określanym jako:

historycznie wykształcona, centralna część miasta, charakteryzująca się przemieszaniem zwartej i intensywnej zabudowy mieszkaniowej (o wysokim na ogół standardzie) z obiektami usługowymi i administracyjnymi, występującymi najliczniej w tej części miasta, a często także z obiektami przemysłowymi" (Nowakowski, 1990, s. 8).

Wydaje się jednak, że tak definiowane śródmieście pozwala odróżnić je od centrum miasta. Śródmieście należy zatem wiązać raczej z jego historycznym charakterem, podczas gdy centrum miasta można wyznaczyć na podstawie nagromadzenia specyficznych funkcji usługowych.

Badacze amerykańscy centrum miasta - rozumianego jako duży ośrodek miejski i delimitowanego jako funkcjonalny region miejski lub obszar metropolitalny (Zborowski, 2005; Winiarczyk-Raźniak, Raźniak, 2012) - określają mianem „central business district” (CBD) lub "core". W literaturze brytyjskiej natomiast stosuje się wymiennie następujące terminy: „city", ,central area", "city center", "town center". W niemieckich opracowaniach używa się sformułowań: „Stadt-Kern” i „Kern” (Boustedt, 1970, za: Zborowski, 2005; Holzner, 1972, za: Zborowski, 2005; Holzner, 1990, za: Zborowski, 2005; Maik, 1997).

$\mathrm{Na}$ atrakcyjność centrum miasta dla jego użytkowników składa się wiele elementów decydujących o sile przyciągania w kontekście społeczno-kulturowym, ekonomicznym i użytkowym.

W kategoriach społeczno-kulturowych centrum miasta stanowi obszar, na którym zachodzą podstawowe zjawiska społeczne, takie jak: przekaz informacji oraz procesy poznawcze realizacji społecznego prestiżu, selekcji, podejmowania decyzji, spolecznej identyfikacji i integracji (Wallis, 1979).

Korzyści ekonomiczne, wynikające z przestrzennej koncentracji i centralnego położenia $\mathrm{w}$ systemie osadniczym usług i instytucji obsługujących ludność, można rozpatrywać $\mathrm{w}$ trzech zakresach: 1) gospodarki miejskiej, 2) punktów usługowych i instytucji, oraz 3) użytkowników przestrzeni centrum miejskiego.
W pierwszym zakresie - miasto jako funkcjonalny system odnosi korzyści z ograniczenia liczby przejazdów i możliwości efektywniejszego systemu komunikacji, jak również z oszczędności w naziemnym i podziemnym wyposażeniu terenu oraz z możliwości wykorzystania tych samych obiektów do różnych celów.

W drugim zakresie - korzyści placówek usługowych i instytucji polegają głównie na możliwościach wspólnego użytkowania urządzeń komunalnych, transportu towarów i pracowników, utrzymania czystości, zabezpieczenia mienia, urządzeń socjalnych.

W trzecim zakresie - użytkownicy przestrzeni centrum czerpią korzyści z ułatwionego dojazdu do punktów zlokalizowanych w pobliżu głównego węzła transportowego oraz dzięki bliskości usytuowania różnorodnych usług i instytucji. Korzyści te polegają zwłaszcza na oszczędności czasu, kosztów transportu i wydatkowanej energii (Nowakowski, 1990).

Rozwijając zagadnienie korzyści, jakie centrum miasta oferuje jego użytkownikom, zauważamy, że są one wielorakie - począwszy od dogodnej i opłacalnej lokalizacji firm i urzędów (co wynika z tzw. korzyści aglomeracji), poprzez możliwości załatwienia różnego rodzaju spraw przez interesantów, aż po dogodne punkty przesiadkowe $w$ ramach komunikacji miejskiej. Korzyści te można najogólniej określić jako „wygoda w eksploatacji”. Wygoda w użytkowaniu zagospodarowania centrum miasta wiąże się $\mathrm{z}$ koncentracją odpowiednich urządzeń, co pozwala na załatwienie wielu spraw „,w jednym miejscu i za jednym razem”. Jak pisał Nowakowski (1990), w centrum o wysoce funkcjonalnym charakterze powinny znajdować się urządzenia i obiekty: po pierwsze - unikatowe (niepodzielne), wysoce wyspecjalizowane i często użytkowane przez dużą liczbę ludności, a po drugie - niezajmujące zbyt dużych powierzchni i nieuciążliwe dla sąsiedztwa.

Urządzenia i obiekty unikatowe to takie, które występują pojedynczo w skali określonego systemu osadniczego (np. ratusz czy opera), albo też zespół urządzeń lub obiektów podobnych, tworzący szczególną wartość polegającą na możliwości wyboru (np. kilka kin zlokalizowanych w pobliżu, sklepy tej samej branży, kawiarnie i restauracje ze zróżnicowaną ofertą gastronomiczną). Jednoczśnie, jako uzupełniające ofertę, w centrum powinny znaleźć się również urządzenia i obiekty codziennego wykorzystania, zaspokajające podstawowe potrzeby ludności (np. sklepy spożywcze, usługi gastronomiczne, służba zdrowia, poczta). 
Należy zwrócić uwagę na fakt, że rozwój centrum miasta, obok korzyści dla samego miasta jako jednostki osadniczej i jego użytkowników, generuje także koszty społeczne i środowiskowe (rys. 1). Są one wynikiem intensyfikacji użytkowania centrów miast, prowadzącej w rezultacie do uciążliwości dla użytkowników, które są związane z zanieczyszczeniem powietrza, hałasem, nagromadzeniem patologii i przestępczości (Nowakowski, 1990; Regulski, 1982).

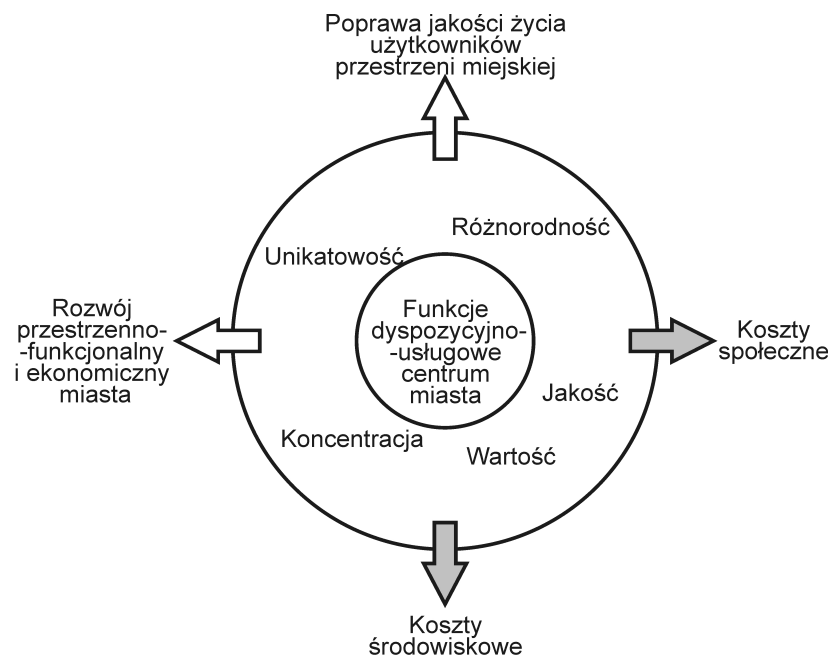

Rys. 1. Oddziaływanie na rozwój miasta funkcji dyspozycyjno-usługowych jego centrum Źródło: opracowanie własne

$\mathrm{W}$ zachodnich modelach funkcjonalnego regionu miejskiego, ze względu na stopień koncentracji działalności centralnych, wyróżnia się zazwyczaj kilka centralnych ośrodków hierarchicznych: 1) centralny ośrodek usługowy, 2) ośrodki dzielnicowe, 3) ośrodki osiedlowe, 4) ośrodki sąsiedzkie, 5) ośrodki lokalne (Maik, 1997). Centralność jest zjawiskiem niezwykle złożonym, polegającym na ogniskowaniu się różnych dziedzin życia, zjawisk gospodarczych, administracyjnych, kulturalnych i innych (Kiełczewska-Zaleska, 1972; Szymańska, 2009). Należy nadmienić, że nagromadzenie usług, jak i innych elementów struktury miasta ( $w$ tym także unikatowych), nie musi mieć charakteru koncentrycznego; wyróżnia się także układy pasmowe i obszary wyspecjalizowane (Berry, 1963, za: Maik, 1997).

O ile centralny ośrodek usługowy odgrywa najważniejszą rolę $\mathrm{w}$ systemie usług miejskich ze względu na liczbę funkcji i rodzajów działalności (jest to swojego rodzaju węzeł miasta, w którym wszystkie widoczne i niewidoczne nici kontaktów lokalnych i ponadlokalnych splatają się), o tyle ośrodki dzielnicowe (subcentra miast) - zlokalizowane zazwyczaj w pobliżu skrzyżowania głównych ulic dzielnicy - scalają życie społeczności dzielnicy umożliwiając korzystanie z pewnych urządzeń i obiektów kulturalnych, handlowych i społeczno-rekreacyjnych. W centrum dzielnicy oprócz sklepów branżowych znajduje się zazwyczaj jeden lub kilka większych lokali handlowo-usługowych (np. domów towarowych), kościól, poczta i inne unikatowe obiekty. Obszar wpływu ośrodka dzielnicowego może objąć do około 100 tys. mieszkańców, a maksymalna odległość czasowa wynosi blisko 25 minut pieszo, co odpowiada odległości 1,5 km (Vresk, 1977, za: Maik, 1997).

\section{METODYKA BADAŃ}

Jako cel badań przyjęto ocenę atrakcyjności wybranych elementów funkcjonowania przestrzeni miejskiej Krakowa (zwłaszcza atrakcyjności usług), $\mathrm{w}$ obrębie centrum miasta oraz centrów dzielnic administracyjnych (pomocniczych jednostek samorządowych) tego miasta, opierając się na opiniach mieszkańców.

$\mathrm{W}$ badaniach wykorzystano informacje pochodzące z 204 kwestionariuszy wywiadów przeprowadzonych wśród respondentów będących mieszkańcami wybranych dzielnic Krakowa. Wywiadami objęto mieszkańców następujących dzielnic administracyjnych: II - Grzegórzki, III - Prądnik Czerwony, IV - Prądnik Bały, V - Krowodrza, VI - Bronowice, VII - Zwierzyniec, VIII - Dębniki, IX - Łagiewniki-Borek Fałęcki, X - Swoszowice, XI - Podgórze Duchackie, XII - Bieżanów-Prokocim, XIII - Podgórze. Należy zaznaczyć, że nie przeprowadzono badań z mieszkańcami Starego Miasta, jak również dzielnic: XIV - Czyżyny, XV - Mistrzejowice, XVI - Bieńczyce, XVII - Wzgórza Krzesławickie oraz XVIII - Nowa Huta, uważanych tradycyjnie przez mieszkańców Krakowa za dużą dzielnicę mieszkaniową Nowa Huta. Nieuwzględnienie ludności z dzielnicy I - Stare Miasto miało charakter intencjonalny, gdyż zamierzeniem autorki było uzyskanie od każdego respondenta rozłącznej oceny odnoszącej się zarówno do centrum miasta, jak i centrum dzielnicy. Mieszkańców Nowej Huty pominięto natomiast ze względu na specyficzne uwarunkowania funkcjonalne i społeczne tej dzielnicy wraz z jej centrum. Nowa Huta w świadomości krakowian stanowi swojego rodzaju odrębny byt 
przestrzenno-funkcjonalny i społeczny. Warto jednak zaznaczyć, że kontynuacją niniejszych badań będzie ocena jakości funkcji usługowych centrum Nowej Huty z punktu widzenia mieszkańców przyległych dzielnic administracyjnych, dla których rejon Placu Centralnego w Nowej Hucie stanowił w przeszłości, i teoretycznie może stanowić również obecnie, konkurencyjne centrum względem Starego Miasta (Brzosko-Sermak, Płaziak, Trzepacz, 2017; Płaziak, 2014; Płaziak, Szymańska, 2017; Winiarczyk-Raźniak, 2008).

Dobór próby badawczej był nieprobabilistyczny, dogodny - podstawę doboru stanowiła dostępność respondentów (mieszkańców wybranych dzielnic Krakowa), a ich struktura demograficzna była zbliżona do struktury wieku i płci dorosłych mieszkańców miasta.

Za centrum Krakowa przyjęto obszar Starego Miasta, natomiast granice centrów dzielnicowych wyznaczono na podstawie nagromadzenia unikatowych funkcji centrotwórczych, występujących na terenie analizowanych dzielnic administracyjnych Krakowa, oraz wskazań respondentów w badaniach poprzedzających.

Wnioskowanie oparto na podstawie danych statystycznych uzyskanych $\mathrm{z}$ badania kwestionariuszowego. Za pomocą odsetków odpowiedzi określono struktury częstotliwości oraz powody odwiedzin obu rodzajów centrów. Obliczono wskaźnik Yule'a w celu wskazania zależności między dwiema cechami dychotomicznymi: istniejącymi preferencjami lub brakiem preferencji konkretnych częstotliwości bywania zarówno w centrum miasta, jak i w centrach dzielnic (przykładowe pytanie w celu uzyskania odpowiedzi do otrzymania cech dychotomicznych: "Czy odwiedza Pan/i centrum miasta codziennie?"). Obliczono również średnie ocen dokonanych przez respondentów wybranych aspektów funkcjonowania centrum miasta i centrów dzielnic.

\section{CZĘSTOTLIWOŚĆ I POWODY ODWIEDZIN CENTRUM MIASTA I CENTRÓW DZIELNIC PRZEZ MIESZKAŃCÓW KRAKOWA}

Wśród respondentów większą częstotliwością odwiedzin cieszą się centra dzielnic administracyjnych niż centrum miasta. Ponad $42 \%$ badanych pojawia się $\mathrm{w}$ centrum swojej dzielnicy kilka razy w tygo- dniu, a prawie $39 \%$ bywa tam codziennie. Niespelna $8 \%$ respondentów odwiedza centrum dzielnicy co najwyżej raz w tygodniu. Nie jest jednak zaskoczeniem taka struktura odpowiedzi wobec bliskości przestrzennej centrum dzielnicy i miejsc zamieszkania respondentów.

Centrum miasta jest odwiedzane kilka razy w tygodniu przez prawie 38\% ankietowanych, natomiast codziennie bywa tam nieco ponad $18 \%$ spośród nich. Raz w tygodniu w centrum pojawia się nieco ponad $12 \%$ respondentów, a raz $\mathrm{w}$ miesiącu - prawie $13 \%$. Spory, bo niemal 10-procentowy udział stanowią osoby wybierające się do centrum tylko w weekend.

Interesujące, że wśród badanych relatywnie duży udział mieli odwiedzający zarówno centrum miasta, jak i centrum dzielnicowe jedynie kilka razy w roku - odpowiednio 7\% i $4 \%$ (rys. 2).

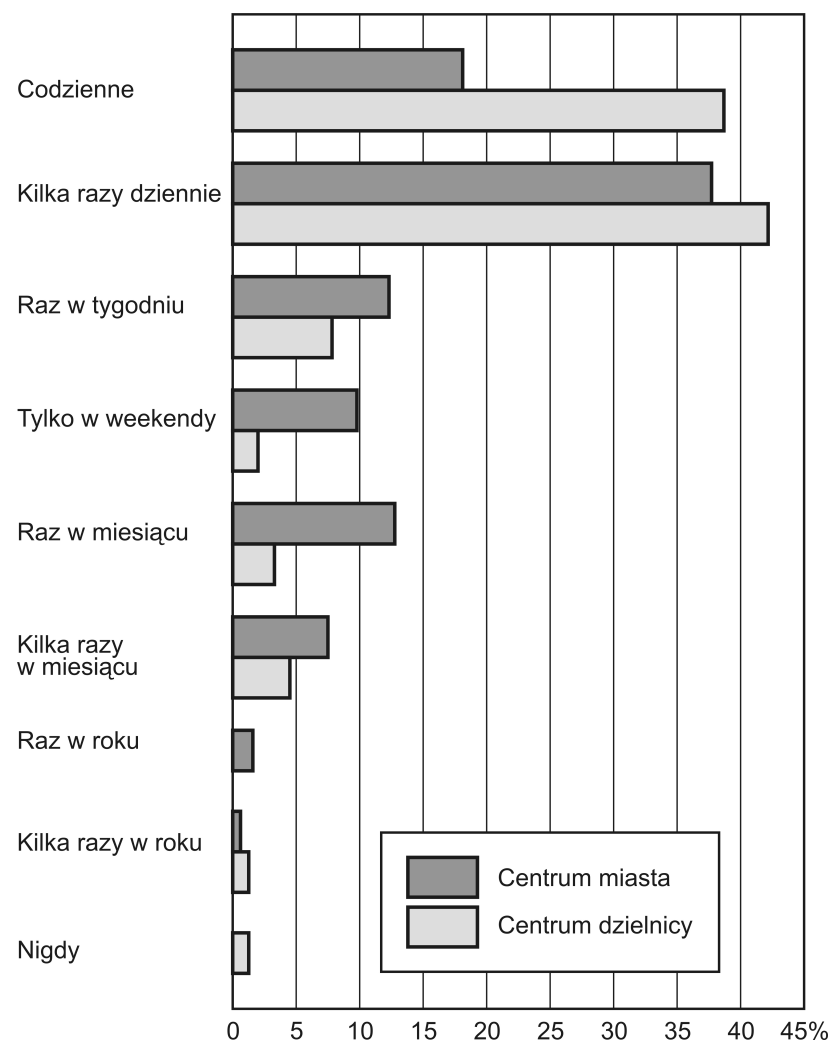

Rys. 2. Częstotliwość odwiedzin centrum Krakowa i centrów jego dzielnic przez respondentów Źródło: opracowanie własne na podstawie kwestionariuszy wywiadu

Na podstawie analizy wartości wskaźnika Yule'a, obliczonego dla dychotomicznych cech deklarowanych lub niedeklarowanych częstotliwości wizyt w centrum miasta i centrach dzielnic, stwierdzono następujące pozytywne zależności: odwiedziny 
centrum miasta kilka razy w tygodniu, a bywanie $\mathrm{w}$ centrum dzielnicy codziennie; wizyty centrum miasta raz $w$ tygodniu a odwiedziny centrum dzielnicy kilka razy $w$ tygodniu; bywanie $w$ centrum miasta tylko w weekend a wizyty w centrum dzielnicy kilka razy w tygodniu (tab. 1).

Osoby odwiedzające centrum dzielnicy codziennie są zatem także skłonne do relatywnie częstego pojawiania się $\mathrm{w}$ centrum miasta (kilka razy w tygodniu). Jednocześnie udający się do centrum dzielnicy dość często, bowiem kilka razy w tygodniu, są skłonni bywać w centrum miasta przynajmniej raz $\mathrm{w}$ tygodniu bądź w weekend. Jednak nie wskazano statystycznie istotnych preferencji odwiedzin codziennych centrum miasta $i$ jednoczesnych preferencji codziennego lub rzadszego bywania w centrum dzielnicy. nie najważniejszym motywem były zakupy $(23,3 \%$ odpowiedzi). Następnym w kolejności powodem był spacer $(17,4 \%)$; okazuje się, że dla respondentów pod tym względem centrum dzielnicy jest bardziej atrakcyjne niż centrum miasta. Jako kolejny motyw bywania $\mathrm{w}$ centrum dzielnicy wskazano spotkania towarzyskie $(12,7 \%)$, jednak w tym zakresie centrum miasta okazało się bardziej atrakcyjne. Następne powody relatywnie częstego bywania w centrum dzielnicy, np. w celu załatwienia spraw urzędowych (10,3\% odpowiedzi) i wizyt związanych ze zdrowiem $(9,0 \%)$, okazały się istotniejsze w przypadku centrów dzielnic niż centrum Krakowa. Zdecydowanie rzadziej respondenci bywający $w$ restauracjach, kawiarniach i klubach znajdujących się w centrum dzielnicy $(8,3 \%)$ niż w centrum miasta.

Tab. 1. Relacje częstotliwości odwiedzin centrum miasta a centrum dzielnic Krakowa przez respondentów w oparciu o wartości wskaźnika Yule'a

\begin{tabular}{|l|l|c|c|c|c|}
\hline \multirow{2}{*}{ Częstotliwość odwiedzin } & \multicolumn{3}{|c|}{ Częstotliwość odwiedzin centrum dzielnicy } \\
\cline { 3 - 6 } \multicolumn{2}{|c|}{} & \multirow{2}{*}{ codziennie } & $\begin{array}{c}\text { kilka razy } \\
\text { w tygodniu }\end{array}$ & $\begin{array}{c}\text { raz } \\
\text { w tygodniu }\end{array}$ & $\begin{array}{c}\text { tylko } \\
\text { w weekend }\end{array}$ \\
\hline \multirow{3}{*}{$\begin{array}{l}\text { Centrum } \\
\text { miasta }\end{array}$} & codziennie & 0,07 & 0,09 & 0,01 & $-0,07$ \\
\cline { 2 - 6 } & kilka razy w tygodniu & $0,33^{*}$ & $-0,11$ & $-0,11$ & 0,04 \\
\cline { 2 - 6 } & raz w tygodniu & $-0,01$ & $0,18^{*}$ & 0,07 & $-0,05$ \\
\cline { 2 - 6 } & tylko w weekend & $-0,01$ & $0,18^{*}$ & 0,02 & $-0,05$ \\
\hline
\end{tabular}

* Wartości wskaźnika Yule'a istotne statystycznie, $a=0,05$.

Źródło: opracowanie własne na podstawie kwestionariuszy wywiadu.

Centrum Krakowa dla respondentów jest atrakcyjne przede wszystkim $\mathrm{w}$ związku $\mathrm{z}$ możliwością zaspokojenia potrzeb związanych z rozrywką, tj. spotkań towarzyskich (17,5\% wskazań) oraz odwiedzin restauracji, kawiarni i klubów (17,5\%). Jednym $\mathrm{z}$ ważniejszych powodów korzystania z centrów są także zakupy (12,5\% wskazań), a kolejne to spacer $(11,1 \%)$ i wizyta w kinie lub teatrze $(10,5 \%)$, jak również uczestnictwo $\mathrm{w}$ imprezach plenerowych $(8,0 \%)$. Relatywnie rzadko uczestniczący w badaniach bywają $\mathrm{w}$ ogólnomiejskim centrum ze względu na wykonywaną pracę $(7,3 \%$ respondentów) lub też podejmowaną nauką $\mathrm{w}$ szkole czy na uczelni $(4,6 \%)$. Podobny odsetek odpowiedzi dotyczył wizyt $\mathrm{w}$ centrum miasta w związku z załatwianiem spraw urzędowych $(4,6 \%)$, a nieco mniejszy - spraw związanych ze zdrowiem $(3,7 \%)$, a także uczestnictwem w kursach doszkalających i zajęciach związanych z uprawianiem hobby (2,8\%) (rys. 3).

Nieco inna struktura odpowiedzi dotyczyła powodów odwiedzin centrów dzielnic. Zdecydowa-
Nieco częściej natomiast pracują w centrum dzielnicy $(7,8 \%$ odpowiedzi) niż w centrum miasta, rzadziej jednak $\mathrm{w}$ centrum dzielnicy pobierają naukę w szkole czy na studiach (3,8\% odpowiedzi) niż w centrum Krakowa, rzadziej też uczestniczą w centrum dzielnicy w kursach doszkalających i zajęciach związanych z hobby (2,7\%). Nieczęsto badane osoby uczestniczą $\mathrm{w}$ centrum dzielnicy $\mathrm{w}$ imprezach plenerowych (2,5\% wskazań), a jeszcze rzadziej bywają w kinie czy teatrze ( $2 \%$ odpowiedzi) (rys. 3 ).

Zaprezentowana na rys. 3 struktura odpowiedzi wydaje się zgodna ze strukturami funkcji, jakie pełnią centra dzielnic i centrum miasta. Centrum ogólnomiejskie oferuje bardziej elitarne, wręcz unikatowe usługi, związane $\mathrm{z}$ zaspokajaniem potrzeb towarzyskich, rozrywkowych i kulturalnych oraz zakupów bardziej ekskluzywnych dóbr, jak również związanych $\mathrm{z}$ załatwieniem spraw $\mathrm{w}$ urzędach wyższej rangi. Centrum dzielnicy obsługuje mieszkańców w zakresie usług bardziej powszechnych i równocześnie łatwo dostępnej rekreacji. Dlatego 
widoczne są stosunkowo częste wskazania atrakcyjności centrum dzielnicy do robienia zakupów, załatwiania spraw urzędowych i wizyt związanych ze zdrowiem, a także odbywania spacerów.

Przedstawione wyniki badań są zgodne $\mathrm{z}$ założeniami ogólnie znanych koncepcji, na czele z teorią ośrodków centralnych Christallera (1963) i teorią lokalizacji działalności gospodarczej Löscha (1961), które wykryły hierarchię zaspokajania potrzeb podstawowych mieszkańców w ośrodku lokalnym i potrzeb bardziej wysublimowanych $\mathrm{w}$ ośrodku wyższego rzędu. $W$ odniesieniu do tych koncepcji centrum dzielnicy mieszkaniowej można traktować jako centrum ośrodka niższego rzędu, a centrum ogólnomiejskie - jako centrum ośrodka wyższego rzędu.

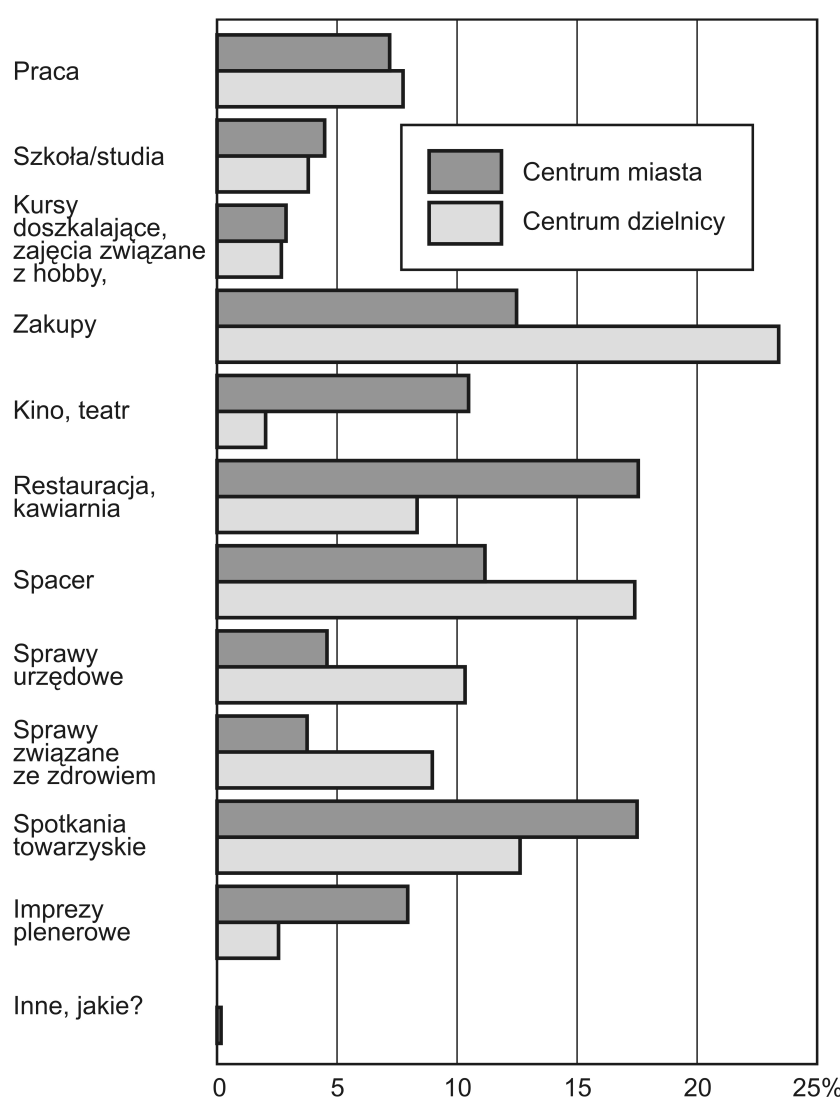

Rys. 3. Powody odwiedzin przez respondentów centrum Krakowa i centrów jego dzielnic Źródło: opracowanie własne na podstawie kwestionariuszy wywiadu

Odnosząc się do hierarchicznych koncepcji zaspokajania potrzeb interesujący wydaje się fakt stosunkowo małego udziału wskazań respondentów w zakresie odwiedzin centrów dzielnic Krakowa w porównaniu do centrum miasta jako miejsca spotkań towarzyskich oraz wizyt w restauracjach, kawiarniach i klubach. Potrzebne są tego rodzaju badania $\mathrm{w}$ celu określenia miejsc tychże potrzeb w ogólnej hierarchii potrzeb mieszkańców miasta. Być może niektóre z nich, związane z rozrywką, powinny być możliwe do realizacji niekoniecznie dopiero w ścisłym centrum miasta, lecz już na poziomie centrum dzielnicy. Niniejsze wyniki badań mogą stanowić dla władz miejskich podstawę do rozważenia doinwestowania centrów dzielnic w tym zakresie.

Centrum Krakowa jest zdecydowanie lepiej postrzegane przez respondentów niż centra dzielnic. Spośród sześciu kategorii potrzeb (skala ocen: od 1 do 5) aż w pięciu kategoriach centrum miasta uzyskało wyższe oceny niż centrum dzielnicy (rys. 4). Były to kategorie dotyczące zarówno funkcji, jak i wygody oraz estetyki. Jedynie poczucie bezpieczeństwa było wyżej oceniane w centrum dzielnicy (średnia 3,7) niż centrum miasta $(3,5)$. Należy zaznaczyć, że zarówno $\mathrm{w}$ odniesieniu do centrum Krakowa, jak i centrów jego dzielnic oceny dotyczące poczucia bezpieczeństwa były niskie w porównaniu do innych kategorii. Zdecydowanie najniżej oceniono oferty kulturalne i rozrywkowe w centrum dzielnicy (średnia 2,9) - rys. 4.

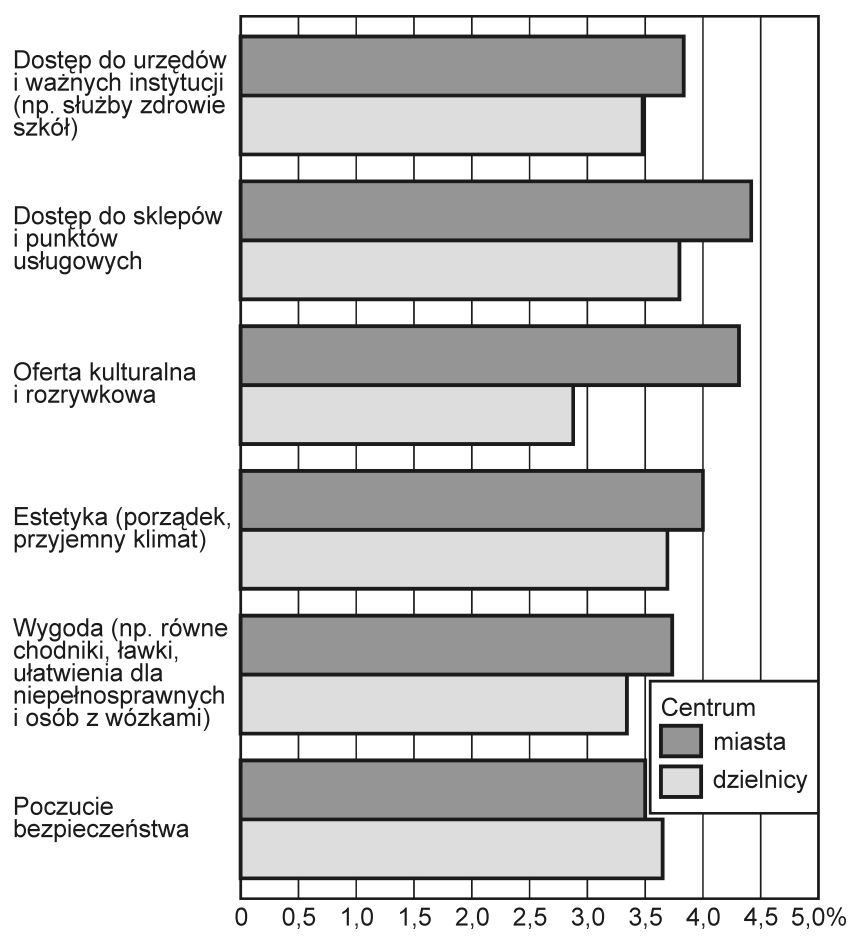

Rys. 4. Jakość centrum Krakowa i centrów dzielnic w ocenie respondentów

Źródło: opracowanie własne na podstawie kwestionariuszy wywiadu

Reasumując wyniki przedstawionych badań kwestionariuszowych można stwierdzić, że zarówno nieduża częstotliwość odwiedzin centrów dzielnic 
przez ankietowanych, jak też niska ocena oferty kulturalnej i rozrywkowej w tych centrach może wskazywać na konieczność przeprowadzenia badań dotyczących preferencji mieszkańców w zakresie uzupelnienia tej oferty.

Ponadto zasługuje na uwagę stosunkowo słabe (zwłaszcza w centrum miasta) poczucie bezpieczeństwa respondentów. Należałoby przeprowadzić badania mające na celu uzyskanie odpowiedzi na pytania: jakie czynniki wpływają na tak niską ocenę zarówno w centrum ogólnomiejskim, jak i centrach dzielnicowych, i czy podobne czynniki oddziałują $\mathrm{w}$ obu tych rodzajach przestrzeni miejskiej, czy nie? Dałoby to wskazania do wprowadzenia środków zaradczych wpływających na poprawę poczucia bezpieczeństwa wśród użytkowników obu rodzajów przestrzeni miejskiej.

\section{PODSUMOWANIE}

Respondenci zdecydowanie częściej odwiedzają centra dzielnic administracyjnych niż centrum Krakowa. Jest to oczywiste ze względu na mniejszą odległość centrum dzielnicowego od miejsca ich zamieszkania, jak również z powodu różnic w poziomie zagospodarowania obu tych rodzajów przestrzeni miejskiej - z ofertą dostosowaną do odmiennych potrzeb ludności. Zaprezentowane badania potwierdzają hierarchiczność zaspokajania potrzeb ludzkich - potrzeby codzienne, takie jak załatwianie podstawowych sprawunków, edukacja niższego szczebla i podstawowe sprawy urzędowe są zazwyczaj zaspokajane w ośrodkach niższego rzędu, czyli centrach dzielnic administracyjnych. Bardziej wymagające potrzeby, związane $\mathrm{z}$ zakupami luksusowych produktów, załatwianiem ważniejszych spraw urzędowych, edukacją na wyższym poziomie i wyszukaną rozrywką realizowane są częściej $\mathrm{w}$ centrum miasta. Jest to ściśle powiązane $\mathrm{z}$ zagospodarowaniem wymienionych jednostek. Niemniej zastanawia zjawisko stosunkowo rzadkich odwiedzin centrów dzielnic Krakowa w stosunku do częstości bywania $\mathrm{w}$ centrum miasta $\mathrm{w}$ związku ze spotkaniami towarzyskimi oraz wizytami w restauracjach, kawiarniach i klubach. Prawdopodobnie powodem tego jest $\mathrm{z}$ jednej strony lepsze zagospodarowanie i większa atrakcyjność kulturalno-rozrywkowa centrum miasta, a $z$ drugiej strony niewystarczająca infrastruktura i słaba oferta $\mathrm{w}$ tym zakresie w obrębie centrów dzielnicowych. Należy więc zbadać zapotrzebowanie mieszkańców w od- niesieniu do rodzaju infrastruktury kulturalno-rozrywkowej oraz ich oczekiwań $w$ tej kwestii w dzielnicach administracyjnych miasta, zwłaszcza $w$ ich centrach.

Stwierdzono statystycznie istotną zależność - im częstsze są odwiedziny konkretnych mieszkańców w centrum dzielnicy, tym częściej odwiedzają oni centrum miasta. W przypadku takich osób niekoniecznie ważna jest oferta obu centrów, lecz predyspozycje lub chęci tych osób do bywania we wspomnianych miejscach. W celu zwiększenia częstotliwości odwiedzin centrum miasta czy centrów dzielnicowych ważne jest nie tylko zwiększenie atrakcyjności tych miejsc, lecz także zmiana stylu życia mieszkańców miasta.

W opinii mieszkańców Krakowa ogólna atrakcyjność centrum miasta jest większa niż atrakcyjność centrów dzielnic administracyjnych. Jedynie względy bezpieczeństwa centrum miasta uzyskały niższą ocenę niż centra dzielnic, przy czym należy zauważyć, że zarówno $\mathrm{w}$ odniesieniu do centrum Krakowa, jak i centrów dzielnic oceny kategorii poczucia bezpieczeństwa były niższe $\mathrm{w}$ porównaniu do innych kategorii. Zdecydowanie najsłabsza ocena dotyczyła kategorii oferty kulturalnej i rozrywkowej w centrach dzielnic administracyjnych.

\section{BIBLIOGRAFIA}

Brzosko-Sermak, A., Płaziak, M., Trzepacz, P. (2017). Przemiany funkcji handlowych i usługowych centrum dzielnicy mieszkaniowej na przykładzie Krakowa-Nowej Huty. Prace Komisji Geografii Przemystu Polskiego Towarzystwa Geograficznego, 31 (2), s. 95-110.

Christaller, W. (1963). Ośrodki centralne w Południowych Niemczech. Przeglad Zagranicznej Literatury Geograficznej, 1, s. 1-72.

Kiełczewska-Zaleska, M. (1972). Geografia osadnictwa. Warszawa: Państwowe Wydawnictwo Naukowe.

Lösch, A. (1961). Gospodarka przestrzenna. Teoria lokalizacji. Warszawa: Państwowe Wydawnictwo Ekonomiczne.

Maik, W. (1997). Podstawy geografii miast. Torun: Uniwersytet Mikołaja Kopernika.

Maliszowa, B. (1974). Śródmieście. Wybrane zagadnienia planowania. Warszawa: Arkady.

Mydel, R. (1991). Rozmiary i dzienny rytm ruchu pieszego w Rynku Głównym miasta Krakowa. Folia Geographica, Series Geographica-Oeconomica, XXVII, s. 13-29.

Nowakowski, M. (1990). Centrum miasta. Teoria, projekty, realizacje. Warszawa: Arkady.

Płaziak, M. (2014). Przemiany funkcji handlowo-usługowych w mieście postsocjalistycznym na przykładzie Nowej Huty (s. 85-100). W: E. Kaczmarska, P. Raźniak (red.) Społeczno-ekonomiczne i przestrzenne przemiany struktur regionalnych, Kraków: Oficyna Wydawnicza AFM.

Płaziak, M., Szymańska, A.I. (2017). Regres czy rozwój lokalnej działalności handlowo-usługowej w najstarszej części Nowej Huty? Przedsiębiorczość - Edukacja, 13, s. 228-243. 
Regulski, J. (1982). Ekonomika miasta. Warszawa: Państwowe Wydawnictwo Ekonomiczne.

Szymańska, D. (2009). Geografia osadnictwa. Warszawa: Wydawnictwo Naukowe PWN.

Wallis, A. (1979). Informacja i gwar - o miejskim centrum. Warszawa: Państwowy Instytut Wydawniczy.

Winiarczyk-Raźniak, A. (2006). Uczestnictwo w kulturze jako przejaw miejskiego stylu życia $\mathrm{w}$ regionie miejskim Krakowa (s. 203-213). W: B. Górz (red.), Urbanizacja i społeczeństwo. Kraków: Wydawnictwo Instytutu Geografii Akademii Pedagogicznej w Krakowie.
Winiarczyk-Raźniak, A. (2008). Wybrane usługi a jakość życia mieszkańców w regionie miejskim Krakowa. Prace Monograficzne Uniwersytetu Pedagogicznego, 508.

Winiarczyk-Raźniak, A., Raźniak, P. (2012). Migracje wewnętrzne ludności w polskich obszarach metropolitalnych u progu XXI wie$k u$. Kraków: Uniwersytet Pedagogiczny.

Zborowski, A. (2005). Przemiany struktury spoteczno-przestrzennej regionu miejskiego w okresie realnego socjalizmu i transformacji ustrojowej (na przykładzie Krakowa). Kraków: Instytut Geografii i Gospodarki Przestrzennej Uniwersytetu Jagiellonskiego.

Artykuł wpłyną:

30 października 2019

Zaakceptowano do druku:

12 grudnia 2019 